\title{
Enforcement of Student Discipline Character, What School Principal Acts?
}

\author{
Syunu Trihantoyo ${ }^{\mathrm{a}}$, Moedjito ${ }^{\mathrm{b}}$ \\ Department of Educational Management, Surabaya State University \\ Surabaya, Indonesia \\ Corresponding e-mail: syunutrihantoyo@unesa.ac.id
}

\begin{abstract}
This study was conducted to know the effort or strategy of principal in improving the character of student discipline. The research method used a qualitative approach. The technique of data collected was by interview, observation, and documentation study. Informants in this study consisted of principals, vice principals, counseling teachers, classroom teachers, school security officers, and students. In improving the character education of student discipline, the results of the research indicate that the principal's effort or strategy by implementing the doctrine program enforced in habituation. Activity habituation through activities: cheerful morning, a congregation of praying Dhuha, tadarus Al-Quran, literation, and memorization of "Limas' doctrine. This result can be a school reference, primarily a faith-based school, to enforce discipline as a character's identity of students.
\end{abstract}

Keywords: discipline character, school principal.

\section{INTRODUCTION}

Education not only builds a person who is knowledgeable or intelligently cognitively, but also raises good attitude and character in daily activities. One of the efforts to improve the quality of education in Indonesia is marked by the emergence of the idea of character education. This idea arises because the educational process that has been done has not been fully successful in building human character. Someone with a weak character, there will be no chance of winning. He is just a loser in society, marginalized in a tight competition process. Because people who have weak characters will easily give up, have no principles, pragmatic and opportunistic. The value of discipline is one determinant of success in the future.

Components of character that include moral knowing, moral feeling, moral action, which is necessary for children to understand, feel, and teach the values of goodness (Lickona, 2012; Pane and Rina, 2015). Character education serves to shape the personality of a person through character education, whose results are seen in a person's actual actions, for example, good behavior, honest, responsible, respect for the rights of others, hard work and so on.

Santrock (2007) character education is a direct approach to moral education by instructing learners about basic moral knowledge to prevent them from engaging in immoral behavior or harm to themselves or others. The habituation of moral education and morals for students is applied both at home and at school, as well as in society, rather than teaching them by proposition or verse. Teachers as the spearhead of the implementation of learning should be able to mix and match an integrated curriculum that can touch all the needs of children. The character is the original state that exists within a person that distinguishes between himself and others.

Ariesandi (2008) describes discipline is the process of training mind and character for children gradually so as to become someone who has self-control and useful for the community. The value of discipline is needed to be a trend setter in every life activity. Discipline' value is a value that must be interpreted as the ability to do the priorities and finish to completion. Wulandari (2014) explains that the value of discipline is an important thing to note in order to build one's character. Starting from the value of the character of discipline will encourage the growth of other good character values, such as responsibility, honesty, cooperation and so on.

Principals should be able to help learners develop their behavior patterns, improve their standards of conduct, and implement rules of conduct as a tool to develop the character of 
discipline at school and at home. The principal also has the responsibility of shaping the discipline of students in aspects of his life, such as time discipline, the discipline of learning, discipline to obey the rules, discipline in attitude, discipline in worship, and discipline in achieving ideals. Discipline is part of a continuing process of teaching or education. This tends to be successful when a Principal uses an effective disciplinary procedure to help students to change unfavorable behavior.

Primary school is the right school to start to grow the character of discipline for learners. Characters cannot be formed instantly, so need to be instilled early on. The goal to be achieved in the formation of the character of discipline for learners is to form a good personality and behave in accordance with prevailing norms. SD Muhammadiyah has a way to apply the character of the discipline of learners. This is done by enacting all the rules of discipline on the students along with strict sanctions for the violators, it is to enforce student discipline. This study answers the problems that occur in schools about character education discipline, especially the actions of the principal in strengthening the character of discipline for students.

Previous research on character education by Mafulah (2015) titled the application of character education of discipline through school culture at SDIT AT-Taqwa Surabaya shows the result that character education manifestation begins with habituation, training, character culture, and self-awareness and discipline attitude. Similarly, Komarudin's (2016) study on the principal's strategy in the implementation of character education at the Junior High School of 1 Julok gave the result that the implementation of the character education enhancement program by requiring every teacher of the field of study to make learning device in accordance with the latest curriculum. From the results of previous research, this researcher is useful to strengthen previous research. Where in this research more focus on the value of student discipline character which is analyzed from the principal strategy in its implementation.

\section{METHODS}

This study uses a qualitative approach and is analytical descriptive. School in this research is SD Muhammadiyah 15 Surabaya. Research data obtained from interviews, observations, and documentation when researchers are in the field. Subjects in this study were Headmaster, Vice Principal, Counseling Teacher, Classroom Teacher, Student, and School Guard as a primary source. While the secondary source was obtained from the observation about the principal's strategy in improving the character education of student discipline.

The procedure in this research is shown in Figure 1:

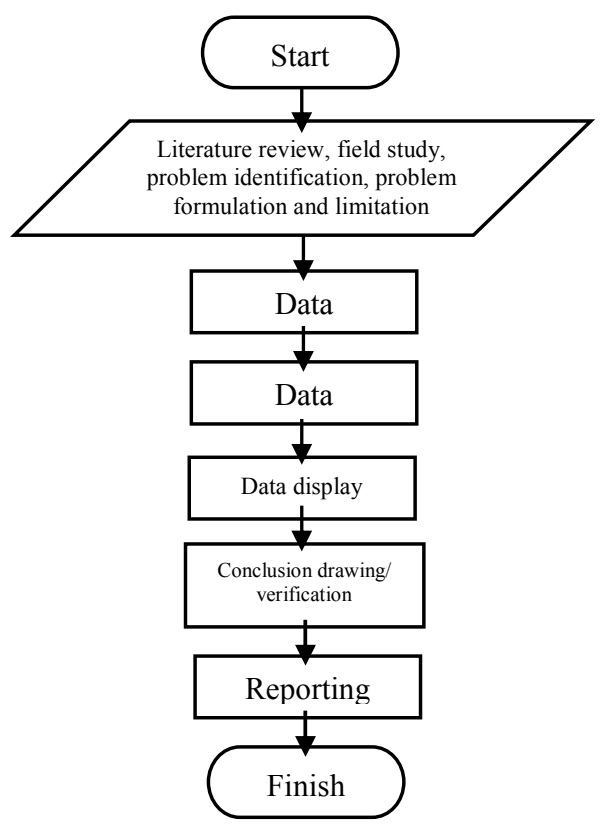

Figure 1 Research procedure.

Figure 1 above shows that in this study using a research procedure that begins with field studies to formulate a research focus. Field studies conducted related to literature review, problem identification, problem formulation, and limitation. After the problem / uniqueness found and found the restrictions of research, then formulate the focus of research, which is related to the principal's strategy in the implementation of student character traits. At this stage, the researcher designed the data collection through interview, observation, and documentation study.

The researchers then collected data on the field and continued with condensation data. Data condensation refers to the process of selecting, focusing, simplifying, abstracting, and / or transforming the data that appears in the full corpus (body) of written-up field notes, interview transcripts, documents and other empirical materials (Miles et all , 2014). The next step is the display, where data is organized into a set of data ready for conclusion drawing and action. The last stage of this research procedure there is to make a research report up to the publication in the proseding or scientific journals to be accessible by educational practitioners in general. 


\section{RESULT AND DISCUSSION}

The data were collected through interviews with informants at SD Muhammadiyah 15 Surabaya on the implementation of student discipline character. Implementation relates to the application of ideas, policies and or innovations on character education based on discipline in schools. Elbla (2012) describes schools' administrators and educators believe that the students are well educated and disciplined pupils. Implementation of disciplinary character education applied to elementary students of Muhammadiyah 15 Surabaya through doctrine program as well as in habituation activities.

The habitation begins with a cheerful morning, where all Ustad and Ustadzah stand in front of the gate to greet the learners who come by applying 5S (smile, greetings, greetings, courtesy, and courtesy). The morning habituation aims at character formation in learners. Habituation is one form of implementation of the Principal to improve character education. Shaking hands with Ustad and Ustadzah is an early activity in a cheerful morning series. Activities with the application of $5 \mathrm{~S}$ are able to form the character of student discipline, where to grow the attitude of discipline required habituation and done at the earliest time in school. The record of observations made by researchers can be seen in table 1 below.

Table 1. Student Activities in Cheerful Morning.

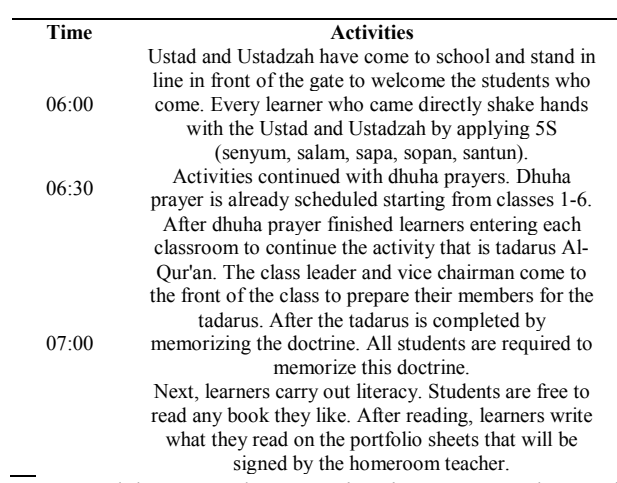

In table 1 above, it is seen that the habituation of implanting the character of discipline is done with support of all school' citizens. Where direct teacher engagement to greet students comes to school in a friendly way, it is able to make students eager to learn. In addition, spiritual strengthening activities are carried out through the congregation dhuha prayer and the Qur'an tadarus. This spiritual strengthening is one of the efforts in supporting the formation of 'Limas' for students.
Implementation of character education cannot be separated from the vision of SD Muhammadiyah 15 Surabaya. The result of the documentation study, the school vision is 'the realization of a superior Islamic education institution based on decency, achievements, and environment which future' oriented. These vision guidelines are used as schools as the foundation for achieving established educational goals.

Principal strategy in implementing the vision by using the methods applied in improving the character education discipline. The method used in SD Muhammadiyah 15 Surabaya like Limas doctrine program. Where the doctrine is a concept that will be implemented in daily habituation program. Like the activities before going to class until the students go home. There are five Limas' doctrines that I am a child of Islam, I am a child of Muhammadiyah, I am a Limas' child, Limas' hands, and the motto of life. This is also done during the learning process takes place. Where implementation is also to foster children's discipline, courage, and responsibility in the classroom. SD Muhammadiyah 15 Surabaya in its implementation also emphasizes the concept of wattawa soubil haaq, wattawa soubilsobri, so it is not only the responsibility of the classroom teacher, not only the principal's responsibility but the whole. This is fully realized by the school because the character is not born of noble rhetoric or merely good intentions, but the character was born of honesty and loyalty attached to moral values (Fahmy, 2015).

In instilling the value of the character to students need habituation is carried out continuously. The character is student identity which is reflected from the way of acting and saying. To that end, embedding characters cannot be done instantly or through a written test that asks students to answer questions. The character is more on the consolidation of heart and soul to do good, discipline in all actions. This commendable deed is not limited to time, whether it will be seen or judged by people or not. One way to cultivate the value of a character, principally discipline, the school performs with examples and actions directly done by the students through various activities that lead to the formation of the doctrine 'Limas' for students. 


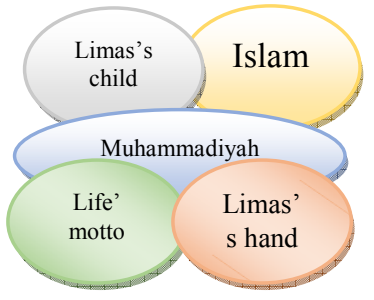

Figure 2 Limas's Doctrines

The indicators for the successful implementation of the Limas doctrine can be seen from the neatness and uniform completeness, timely arrival, timeliness of task, concentration in learning, ethics or student behavior, religious observance. Where good character is the inward motivation to do what is right, according to the highest standard of behavior in every situation (Rokhman, 2014). The school also develops inspirational book building to support student behavior habituation. In the book, there is order and sanctions. The penalties are gradually granted, from being called, reminded, up to parent calling. The purpose of character education activities of the sufficient economy and the integration of the sufficiency economy classes etc (Wongwung, 2014).

Parent involvement is required in growing character values. In one-day student activity is divided between at home, school, and community environment. For that required synergistic between the three components. Awareness of character formation of students needs to be strengthened at home and society. This means that character has invested in the value of decency needs to be controlled by the parents at home. Child activities while at home need to be controlled. In SD Muhammadiyah 15 Surabaya also involves parents of students. Inspirational book building also serves as a connection book. Where the book describes the activities of students who must be known by parents.

\section{CONCLUSIONS}

It was concluded that the implementation of character education in elementary school Muhammadiyah 15 Surabaya required a program of habituation starting from the morning before entering the classroom until school. These habituation activities include cheerful morning, dhuha prayer, and continued tadarus in the classroom, memorization of Limas doctrine, literacy and learning process. To realize these goals cannot be separated from the intervention of some related parties to achieve the goal of disciplining learners.
The above conclusions provide theoretical and practical implications, in which character education is an education to shape one's personality through character education, whose results are seen in one's actual actions, that is discipline in acting and saying. This process is formed in each student's self through daily habits.

\section{ACKNOWLEDGMENT}

The authors acknowledge the contribution of students majoring in educational management for assistance in performing data collection and Faculty of Education, Universitas Negeri Surabaya which fully supports the publication of this study results.

\section{REFERENCES}

[1] Ariesandi. 2008. Rahasia Mendidik Anak Agar Sukses Dan Bahagia, Tips Dan Terpuji Melejitkan Potensi Optimal Anak. Jakarta: PT Gramedia Pustaka Utama.

[2] Elbla, Alawia Ibrahim Farag. 2012. "Is Punishment (Corporal Or Verbal) An Effective Means of Discipline In Schools? : Case Study Of Two Basic Schools In Greater Khartoum/Sudan". Journal Procedia- Social And Behavioral Sciences (Online), Vol 69. Pages 1656-1663.

[3] Fahmy, Rahmi. Dkk. 2015. "Measuring Student Perceptions To Personal Characters Building In Education: An Indonesian Case In Implementing New Curriculum In High School”. Journal Procedia- Social And Behavioral Science (Online), Vol. 211. Pages 851858.

[4] Lickona, Thomas. 2012. Educating For Character: Membentuk Untuk Membentuk Karakter. Jakarta: Bumi Aksara.

[5] Miles, Mathew B., Michael Huberman, and Johnny Saldana. 2014. Qualitative Data Analysis-Third Edition. London: Sage Publication Ltd.

[6] Pane, Mury Made And Rina Patriana. 2015. "The Significance Of Environmental Contents In Character Education For Quality Of Life". Journal Procedia- Social And Behavioral Sciences (Online), Vol.222 Pages 244-252.

[7] Rokhman, Fathur. 2014. "Character Education For Golden Generation 2045 
(National Character Building For Indonesian Golden Years)". Jurnal Procedia- Social And Behavioral Sciences (Online), Vol 141. Pages 1161-1165.

[8] Santrock, John. 2007. Perkembangan Anak. Jakarta: Erlangga.

[9] Wongwung, Adis. 2014."Change Model Of Attributes Of Students In Terms Of Discipline, Sufficiency
Living And Public Mind Fromcharacter Education Activities". Jurnal ProcediaSocial And Behavioral Sciences (Online), Vol.166 Pages 3996-3999.

[10] Wulandari, Meiyanti. 2014. Upaya Peningkatan Kedisiplinan Siswa Melalui Pendidikan Kewarganegaraan. Jurnal Ilmiah PPKn IKIP Veteran Semarang.(Online), Vol. 2 No.1 Hal 44-45. 